\title{
The weekend effect: now you see it, now you don't
}

\author{
(ब) (1) OPEN ACCESS \\ New evidence reinforces concerns about the government's use of evidence
}

\author{
Martin McKee professor of European Public Health
}

London School of Hygiene and Tropical Medicine, London WC1H 9SH, UK

Those who yearn for a world in which policies are based on a systematic and dispassionate assessment of the evidence can find little encouragement in the ongoing debate about the safety of hospitals at weekends. Almost nothing is clear in this tangled tale. It began when the health secretary, Jeremy Hunt, claimed on the BBC Today programme that there were 6000 avoidable deaths each year and a lack of weekend cover by consultants was a key factor. ${ }^{1}$ Yet the evidence to support this claim was elusive. Sometimes the Department of Health pointed to a 2012 paper on hospital mortality. ${ }^{2}$ Other times, and contrary to the government's code of practice on use of statistics, they mentioned a (then) yet to be published paper in The BMJ. ${ }^{3}$ The problem was that, while both did identify an increase in deaths among those admitted at weekends, neither attributed it to a shortage of medical staff. Both identified numerous possible explanations, including various data artefacts. Indeed, the second paper stated explicitly that "to assume that [these deaths] are avoidable would be rash and misleading."”

Yet, notwithstanding this considerable uncertainty, the government sought major changes in hospital staffing, somehow shifting its attention away from consultants to doctors in training. In an unprecedented move, the editor of this journal wrote to the health secretary asking him to desist from further misleading claims based on The BMJ paper by Freemantle and colleagues. ${ }^{3}$ The subsequent government decision to impose a new contract was mired in confusion. ${ }^{4}$

The only good thing to have come out of this process is that it has stimulated a series of studies that seek to resolve the uncertainties identified by the authors of the initial papers and in accompanying commentaries. ${ }^{5}$ In a linked paper, $\mathrm{Li}$ and Rothwell (doi:10.1136/bmj.i2648) used data from a population based stroke register to evaluate the quality of administrative data on patients admitted to hospital with stroke. ${ }^{6}$ The choice of stroke is appropriate because it is a condition for which specialist management in the acute stage can considerably improve survival. Although few will be surprised, the authors identify substantial problems with the data. Only three quarters of new strokes could be identified from the administrative data, and more than a third of episodes were incorrectly coded as admissions for acute stroke. Crucially, many people with apparent new strokes admitted during the week were actually patients undergoing investigations or procedures related to earlier strokes; these patients were much less likely to die. An analysis limited to patients with genuine new strokes found no weekend effect. This study provides support for two of the alternative explanations for the weekend effect, data artefact and case mix.

Three other recent studies have filled other gaps. Aldridge and colleagues examined the work of consultants at weekends. ${ }^{7}$ Again, using crude data, they found a increase in mortality at the weekend but, while noting several limitations such as a low response rate among consultants, were unable to show any association between the intensity of consultant input to patient care and mortality.

Bray and colleagues also studied stroke outcomes using a clinical database that overcame many limitations of administrative data. ${ }^{8}$ Using sophisticated adjustment for case mix, they found no weekend increase in mortality but did find complex variation in the use of investigations and treatment, with patients admitted on weekday nights faring worst.

Finally, Meacock and colleagues examined the important question of whether the threshold for admitting patients is higher at weekends, finding that it is. ${ }^{9}$ As suspected, patients getting over this higher weekend threshold are sicker and more likely to die. Once again, the weekend effect disappears after appropriate adjustment.

Collectively, these studies answer some of the outstanding questions. They show that at least part of the weekend effect is data artefact and, consistent with evidence that was available when the health secretary made his initial statement, any remaining association between weekend admission and mortality does not seem to be due to hospital medical staffing. ${ }^{10}$ However, they also raise other questions. The reported weaknesses of administrative data cast further doubt on the use of measures such as hospital standardised mortality rates. ${ }^{11}$ And to the extent that a weekend effect does exist, what is the appropriate response? The available evidence points to a need for 
improvements in availability of primary care and possibly nurse staffing, but much more research is needed. ${ }^{12}$

The most interesting question, however, is how, in the face of what we now know, the Department of Health can still insist that doctors in training must accept a new contract to address any weekend effect? One possibility is that the department has an ulterior motive, viewing the failure of contract negotiations as a means to achieve local pay bargaining. Another is that ministers are simply displaying a range of cognitive biases that collectively prevent any admission of error or the learning and change of direction that should follow. Arguably, this is the next question that researchers might turn to, taking their cue from the World Bank, which has set the standard for learning organisations to aspire to. ${ }^{13}$ However, such research is unlikely to be undertaken any time soon.

Competing interests: I have read and understood the BMJ Group policy on declaration of interests and declare the following interests: I am on the board of UCL Partners (http://www.uclpartners.com/).

Provenance and peer review: Commissioned; not externally peer reviewed.

1 News BBC. Jeremy Hunt: 'We have 6,000 avoidable deaths every year'. 2015 http://www. bbc.co.uk/news/health-33546800.

2 Freemantle N, Richardson M, Wood J, et al. Weekend hospitalization and additional risk of death: an analysis of inpatient data. J R Soc Med 2012;105:74-84. doi:10.1258/jrsm. 2012.120009 pmid:22307037.

3 Freemantle N, Ray D, McNulty D, et al. Increased mortality associated with weekend hospital admission: a case for expanded seven day services?BMJ 2015;351:h4596. doi: 10.1136/bmi.h4596 pmid:26342923.
4 Elgot J. Health chief: letter backing 'whatever is necessary' on contracts was not agreed. The Guardian $2016 \mathrm{http} / / \mathrm{www}$.theguardian.com/society/2016/feb/12/health-chief-letterwhatever-necessary-contracts-not-agreed.

5 McKee M. Is the UK government right that seven day working in hospitals would save 6000 lives a year?BMJ 2015;351:h4723. doi:10.1136/bmj.h4723 pmid:26342818.

6 Li L, Rothwell PM. Biases in detection of apparent "weekend effect" on outcome with administrative coding data: population based study of stroke. BMJ 2016;353:i2648.

7 Aldridge C, Bion J, Boyal A, et al. HiSLAC Collaborative. Weekend specialist intensity and admission mortality in acute hospital trusts in England: a cross-sectional study. Lancet and admission mortality in acute hospital trusts in England: a cross-sectional study. Lancet 2016 May 10 .

8 Bray BD, Cloud GC, James MA, et al. SSNAP collaboration. Weekly variation in health-care quality by day and time of admission: a nationwide, registry-based, prospective cohort study of acute stroke care. Lancet 2016 May 10:S0140-6736(16)30443-3. doi:10.1016/ S0140-6736(1016)30443-30443. pmid:27178477.

9 Meacock R, Anselmi L, Kristensen SR, Doran T, Sutton M. Higher mortality rates amongst emergency patients admitted to hospital at weekends reflect a lower probability of admission. J Health Serv Res Policy 2016 May 6. doi:10.1177/1355819616649630.

10 Bray BD, Ayis S, Campbell J, et al. Associations between stroke mortality and weekend working by stroke specialist physicians and registered nurses: prospective multicentre cohort study. PLoS Med 2014;11:e1001705. doi:10.1371/journal.pmed.1001705 pmid: 25137386.

11 Hogan H, Zipfel R, Neuburger J, Hutchings A, Darzi A, Black N. Avoidability of hospital deaths and association with hospital-wide mortality ratios: retrospective case record review and regression analysis. BMJ 2015;351:h3239. doi:10.1136/bmj.h3239 pmid:26174149.

12 Black N. Is hospital mortality higher at weekends? If so, why? Lancet 2016 May 10:S0140-6736(16)30505-0. doi:10.1016/S0140-6736(1016)30505-30500. pmid:27178478.

13 McKee M, Stuckler D. Reflective practice: how the World Bank explored its own biases. Int J Health Policy Manag 2015;5:79-82. doi:10.15171/ijhpm.2015.216 pmid:26927392.

Published by the BMJ Publishing Group Limited. For permission to use (where not already granted under a licence) please go to http://group.bmj.com/group/rights-licensing/ permissions

This is an Open Access article distributed in accordance with the Creative Commons Attribution Non Commercial (CC BY-NC 3.0) license, which permits others to distribute, remix, adapt, build upon this work non-commercially, and license their derivative works on different terms, provided the original work is properly cited and the use is non-commercial. See: http://creativecommons.org/licenses/by-nc/3.0/. 